\title{
Pensononowoor
}

2020, vol. 84, 39-48

https://doi.org/10.12657/denbio.084.004

\author{
Zhen Zhang, Guoqing Jin*, Zhichun Zhou
}

\section{Seedling growth, root development and nutrient use efficiency of Cypress clones in response to calcium fertilizer}

Received: 12 April 2020; Accepted: 11 November 2020

\begin{abstract}
Cypress (Cupressus funebris Endl.) is an important tree species in the subtropical regions of China; it is also a major tree species for afforestation and forest land restoration under low-fertility soil conditions. Cypress is considered a calcicolous tree, and its growth and development can be promoted significantly by exchangeable calcium $\left(\mathrm{Ca}^{2+}\right)$ in the soil. However, most of the subtropical regions have low-fertility acidic soils, in which $\mathrm{Ca}^{2+}$ gradually becomes a limiting element for Cypress growth. In this study, different concentrations of $\mathrm{Ca}^{2+}$ fertilizer were added under fertile soil $\left(3 \mathrm{~g} \mathrm{~kg}^{-1}\right.$ NPK fertilizer added) and low-fertility soil ( $0 \mathrm{~g} \mathrm{~kg}^{-1} \mathrm{NPK}$ fertilizer added) conditions. Cypress clones responded differently to $\mathrm{Ca}^{2+}$ addition in different soil conditions. The seedling height and dry matter quality of Cypress in fertile soil were significantly greater than those in low-fertility soil, but plant height and dry biomass did not differ significantly among $\mathrm{Ca}^{2+}$ treatments. The accumulation efficiencies of nitrogen $(\mathrm{N})$, phosphorous $(\mathrm{P})$ and $\mathrm{Ca}$ all differed significantly among the $\mathrm{Ca}^{2+}$ treatments. In low-fertility soil, the addition of $3 \mathrm{~g} \mathrm{~kg}-1 \mathrm{Ca}^{2+}$ significantly promoted development of roots $0.5-2 \mathrm{~mm}$ in diameter, and both the $\mathrm{C} 1$ and $\mathrm{C} 2$ clones achieved their highest $\mathrm{N}, \mathrm{P}$ and $\mathrm{Ca}$ accumulation efficiencies. When the $\mathrm{Ca}^{2+}$ concentration increased to $6 \mathrm{~g} \mathrm{~kg}^{-1}$, the seedling height, dry matter quality and root development were lower than those of the $3 \mathrm{~g} \mathrm{~kg}^{-1} \mathrm{Ca}^{2+}$ treatment. In the fertile soil, the addition of $\mathrm{Ca}^{2+}$ significantly inhibited development of roots $0.5-1 \mathrm{~mm}$ in diameter. The highest $\mathrm{N}$ accumulation efficiency was achieved under the $0 \mathrm{~g} \mathrm{~kg}^{-1} \mathrm{Ca}^{2+}$ treatment, and the highest $\mathrm{Ca}$ accumulation efficiency was achieved under the $6 \mathrm{~g} \mathrm{~kg}^{-1} \mathrm{Ca}^{2+}$ treatment. Seedling height, root dry weight, roots $0-1.5 \mathrm{~mm}$ in diameter and $\mathrm{Ca}$ accumulation showed a significant interaction effect between NPK fertilizer and $\mathrm{Ca}^{2+}$. Therefore, Ca accumulation was more efficient in low-fertility soils. Under low-fertility soil conditions, the addition of $\mathrm{CaSO}_{4}$ can promote the root development of seedlings and advance and prolong the fast growth period of seedling height. Cypress clones can be used as an important tree species for afforestation under low-fertility soil conditions, especially under calcareous soil conditions.
\end{abstract}

Keywords: Cupressus funebris, root development, nutrient accumulation efficiency, calcium response, fertile soil, low fertility soil

Address: Z. Zhang, G. Jin, Z. Zhou, Research Institute of Subtropical Forestry,

Chinese Academy of Forestry, Daqiao Rd 73, Fuyang area, Hangzhou 311400, P. R. China,

e-mail: jgqin@163.com

*Corresponding author 


\section{Introduction}

Calcium $\left(\mathrm{Ca}^{2+}\right)$ is an essential nutrient required for plant growth and development (Kudla et al., 2010; Rashid et al., 2020). Plants generally have a $\mathrm{Ca}^{2+}$ content ranging from $0.1-5.0 \%$, and this element plays a role in maintaining the stability of plant cell walls, cell membranes and membrane-bound proteins, modulating inorganic ion transport and regulating various enzyme activities (Kinzel, 1989; White \& Broadley, 2003; Hepler, 2005; Abbasi \& Manzoor, 2013). Co-application of $\mathrm{Ca}^{2+}$ and other elements, such as nitrogen $(\mathrm{N})$, phosphorous $(\mathrm{P})$ and potassium $(\mathrm{K})$, can modulate intracellular $\mathrm{Ca}^{2+}$ levels, promote seedling growth and root development and enhance plant stress resistance (Jammes et al., 2011; Liu et al., 2018). Applying an appropriate amount of $\mathrm{Ca}^{2+}$ fertilizer to forest trees, such as Chinese fir [Cunninghamia lanceolata (Lamb.) Hook.], can facilitate root development and increase N, P and $\mathrm{K}$ uptake by seedlings (Rashid et al., 2020). Despite the various benefits of $\mathrm{Ca}^{2+}$ for plant growth, high concentrations of $\mathrm{Ca}^{2+}$ often have an inhibitory effect on plant growth and development (Chan et al., 2008).

The root is an important organ of plants for resource acquisition, and the spatiotemporal distribution of plant roots determines the amounts of water and nutrients that are absorbed for photosynthesis and harvest products (Hodge, 2004; Mommer et al., 2012; Rogers \& Benfey, 2015). In different growth conditions, functional attributes such as root number and morphology have differential responses to changes in underground resources. As the most dynamic and physiological component of the underground part of plants, fine roots have gradually become the focus of plant growth and foraging strategies. Usually, fine roots are defined as all roots $\leq 2$ $\mathrm{mm}$ in diameter, and these roots are important organs that allow trees to absorb water and nutrients (Meinen et al., 2009). Due to the continuous formation, senescence, death and regrowth of fine roots, when the soil environment is altered, the length growth rate of fine roots becomes faster or slower, and the mean root diameter becomes thicker or thinner in a short amount of time; the duration of such changes varies (Strand et al., 2008; Kong et al., 2014). According to a functional classification system, roots $\leq 2 \mathrm{~mm}$ in diameter are classified as absorptive and transport fine roots. Absorptive fine roots represent the most distal roots, which are involved primarily in the acquisition and uptake of soil resources, whereas transport fine roots are more common in the branching hierarchy and serve primarily structural and transport functions with some additional capacity for storage. It is assumed that roots $\leq$ $1.0 \mathrm{~mm}$ in diameter are absorptive roots and roots
$1.0-2.0 \mathrm{~mm}$ in diameter are transport roots. Considerable differences in biomass exist between these two root types among different tree species (McCormack et al., 2015). Resource uptake and transport also vary consistently among fine root orders. In particular, uptake capacity declines with increasing root order, while transport capacity increases (McCormack et al., 2017). At present, the relationship between root functional traits and nutrient uptake of forest trees is not very clear, and this relationship directly determines the foraging strategies of different tree species and affects the ability of different genotypes of the same tree species to obtain nutrients under significantly different site conditions (Chen et al., 2016). Recent studies suggest that the diameter of absorptive roots, which affects the carbon costs of constructing root length, also influences root foraging strategies for mineral nutrients (Eissenstat et al., 2015; Liu et al., 2015).

Plants growing in acidic or low base-saturation soils are prone to $\mathrm{Ca}^{2+}$ deficiency (Goulding, 2016). $\mathrm{Ca}^{2+}$ deficiency has gradually emerged as a limiting factor that influences the growth of forest trees. In the subtropical regions of China, fast-growing plantations are primarily distributed in large areas of hills and mountains, and these areas are mostly covered by low-fertility acidic red soils. Due to heavy rainfall and strong weathering in southern China, soil acidification is serious. Acid deposition areas are continuously expanding along with a serious loss of base ions, especially $\mathrm{Ca}^{2+}$ in the soil. This condition results in a deficiency of soil nutrients and a decline in soil fertility, which in turn severely restricts the growth and development of forest trees and the productivity of forest stands (Azevedo et al., 2013).

Cypress (Cupressus funebris Endl.) is an important tree species in the subtropical regions of China, mainly occurring in the Yangtze River Basin and to the south. Cypress is highly adaptive and can grow in a variety of site conditions, especially on limestone mountains (including acidic or weakly alkaline soils); thus, it is also a major tree species for afforestation and forest land restoration under low-fertility soil conditions. Cypress is a calcicole, and its growth and development can be promoted significantly by exchangeable $\mathrm{Ca}^{2+}$ in the soil. However, most subtropical regions have low-fertility acidic soils, in which $\mathrm{Ca}^{2+}$ gradually becomes a limiting element for Cypress growth. Previous research has found substantial variation in the root length of Cypress when the soil environment is disturbed; this effect is long lasting and, in particular, has a great effect on the number, morphology and function of fine roots (Brunner et al., 2019). However, there are diverse types of soil with a wide variety of physicochemical properties in areas where Cypress is distributed. Soil types and physicochemical properties have 
important effects on the growth, distribution and activity of plant roots. Soil fertility determines the ability to supply nutrients to plants. Soil types and physicochemical properties, soil particle composition and total porosity differ. Through the continuous movement of air, water and nutrients in the soil, the nutrient content changes, which further affects the growth and development of roots. For example, clay has high water content and poor soil permeability, which will lead to a shorter root system and decreased root dry weight. However, various plants have different needs for soil types and often show differing comprehensive reflections of soil physicochemical properties (Katerji \& Mastrorilli, 2009). Few data have been reported on root development and nutrient use of Cypress in response to $\mathrm{Ca}^{2+}$ across different soil environments. The effect of $\mathrm{Ca}^{2+}$ availability on diversity of root traits and plant growth has been poorly studied. Research is therefore needed to identify the optimal $\mathrm{Ca}^{2+}$ availability/ accessibility for the seedling growth and root development of Cypress, as the results play major indicative roles in improving seedling quality and forest tree productivity (Tracy et al., 2019; Paez-Garcia et al., 2015).

\section{Materials and methods}

\section{Experimental site and materials}

The experiment was conducted in a greenhouse of Laoshan Forestry Farm in Zhejiang Province, China. The semi-lignified branches from 4-year-old Cypress seedlings were collected as the propagation materials from elite individual plants of clone $\mathrm{C} 1$ (fast height growth) and clone $\mathrm{C} 2$ (slow height growth) in the full-sib progeny. A 1:1 ratio of riversand to loess was used as the cutting medium, and shading measures were performed at the same time. The cutting seedbed temperature was $22{ }^{\circ} \mathrm{C}$, and the air humidity was $90 \%$. The seedlings were selected based on their plant height $(5.15 \pm 0.05 \mathrm{~cm})$ and ground diameter $(0.17 \pm 0.01 \mathrm{~cm})$ after surviving cuttage. These seedlings were planted in containers with a height of $30 \mathrm{~cm}$ and diameter of $20 \mathrm{~cm}$. The potting soil was an acidic red soil collected from forestland, and the soil layer was $0-20 \mathrm{~cm}$ thick. The physicochemical properties of the soil are provided in Table 1 . The controlled-release fertilizer used in the experiment was a nursery fertilizer (APEX, USA).

\section{Experimental design}

NPK fertilizer was added at 3 and 0 g per $\mathrm{kg}$ of soil to simulate fertile and low-fertility soils, respectively. For $\mathrm{Ca}^{2+}$ fertilizer, $\mathrm{CaSO}_{4}$ was added at 0,3 and $6 \mathrm{~g}$ per $\mathrm{kg}$ of soil. Both NPK fertilizer and $\mathrm{CaSO}_{4}$ were mixed with their respective soil, stirred uniformly and placed into the containers. The experiment involved six treatments. Treatment 1 (T1): 3 $\mathrm{g} \mathrm{kg}^{-1} \mathrm{NPK}$ fertilizer $+0 \mathrm{~g} \mathrm{~kg}^{-1} \mathrm{CaSO}_{4}$; treatment 2 (T2): $3 \mathrm{~g} \mathrm{~kg}^{-1} \mathrm{NPK}$ fertilizer $+3 \mathrm{~g} \mathrm{~kg}^{-1} \mathrm{CaSO}_{4}$; treatment 3 (T3): $3 \mathrm{~g} \mathrm{~kg}^{-1} \mathrm{NPK}$ fertilizer $+6 \mathrm{~g} \mathrm{~kg}^{-1}$ $\mathrm{CaSO}_{4}$; treatment 4 (T4): $0 \mathrm{~g} \mathrm{~kg}^{-1} \mathrm{NPK}$ fertilizer +0 $\mathrm{g} \mathrm{kg}^{-1} \mathrm{CaSO}_{4}$; treatment 5 (T5): $0 \mathrm{~g} \mathrm{~kg}^{-1} \mathrm{NPK}$ fertilizer $+3 \mathrm{~g} \mathrm{~kg}^{-1} \mathrm{CaSO}_{4}$; and treatment 6 (T6): $0 \mathrm{~g} \mathrm{~kg}^{-1}$ NPK fertilizer $+6 \mathrm{~g} \mathrm{~kg}^{-1} \mathrm{CaSO}_{4}$. The experiment used a completely randomized block design. During seedling cultivation, the plants were watered every 10 days, and weeding, shading $(75 \%)$ and pest control were performed. Twenty cutting seedlings were planted per treatment per clone, with three replicates each; therefore, 720 potted seedlings were planted.

\section{Cultivation, harvest and analysis}

The experiment was started on April 2, 2018, and plant height and ground diameter were measured for all plants. Thereafter, plant height was measured for each plant once every 20 days. Measurements were completed in November 2018, and continuous data for plant height were used to analyse the plant height growth pattern of Cypress. Seedlings were harvested on November 23. Whole plants were collected and divided into roots, stems and leaves, with each organ harvested separately. First, the roots were separated from the soil, washed with deionized water and stored. Root diameter was classified as follows: class D1 (root diameter range: $0-0.5 \mathrm{~mm})$, class D2 (0.5$1.0 \mathrm{~mm})$, class D3 $(1.0-1.5 \mathrm{~mm})$, class D4 (1.5-2.0 $\mathrm{mm}$ ) and class D5 (> $2.0 \mathrm{~mm}$ ) (Liu et al., 2018). The root length, surface area and root volume of each diameter class were measured using the image analysis software WinRHIZO Pro STD1600+ (Regent Instruments, Canada). Next, the roots, stems and leaves were deactivated in an oven at $105^{\circ} \mathrm{C}$ for 30 min and then dried at $80^{\circ} \mathrm{C}$ until a constant weight was achieved in order to obtain the dry biomass of each part. The $\mathrm{N}$ content of each organ was measured using a FOSS (Foss Sossanalytizal a-s., Ahlleroed, Denmark) nitrogen analyser (Anderson \& Ingram, 1993). The $P$ content was measured by molybdenum

Table 1. Physical and chemical properties of potted soil

\begin{tabular}{|c|c|c|c|c|c|c|c|c|c|}
\hline $\begin{array}{l}\text { Nutrient } \\
\text { elements }\end{array}$ & $\begin{array}{l}\text { Total N } \\
\left(\mathrm{g} \bullet \mathrm{kg}^{-1}\right)\end{array}$ & $\begin{array}{l}\text { Total P } \\
\left(\mathrm{g} \bullet \mathrm{kg}^{-1}\right)\end{array}$ & $\begin{array}{c}\text { Hydrolytic N } \\
\left(\mathrm{mg} \bullet \mathrm{kg}^{-1}\right)\end{array}$ & $\begin{array}{c}\text { Available K } \\
\left(\mathrm{mg} \bullet \mathrm{kg}^{-1}\right)\end{array}$ & $\begin{array}{c}\text { Available P } \\
\left(\mathrm{mg} \bullet \mathrm{kg}^{-1}\right)\end{array}$ & $\begin{array}{c}\text { Organic matter } \\
\left(\mathrm{g} \bullet \mathrm{kg}^{-1}\right)\end{array}$ & $\begin{array}{c}\text { Exchange Ca } \\
\left(\mathrm{mg} \bullet \mathrm{kg}^{-1}\right)\end{array}$ & $\begin{array}{c}\text { Exchange } \mathrm{Mg} \\
\left(\mathrm{mg} \bullet \mathrm{kg}^{-1}\right)\end{array}$ & $\mathrm{pH}$ value \\
\hline $\begin{array}{l}\text { Average } \\
\text { content }\end{array}$ & $0.75 \pm 0.09$ & $0.32 \pm 0.05$ & $53.5 \pm 4.70$ & $18.5 \pm 1.12$ & $0.99 \pm 0.14$ & $15.8 \pm 1.89$ & $128 \pm 12.5$ & $9.24 \pm 0.85$ & $4.65 \pm 0.21$ \\
\hline
\end{tabular}


antimony anti-colorimetry (He et al., 2013). The Ca content was measured by atomic absorption spectrophotometry (Rashid et al., 2020). The N, P and Ca contents were multiplied by the dry biomass of the whole plant to obtain the N, P and Ca accumulation. $\mathrm{N}$ accumulation efficiency $=$ dry biomass accumulation of the whole plant/N uptake of the whole plant $\left(\mathrm{g} \mathrm{mg}^{-1}\right)$; $\mathrm{P}$ and $\mathrm{Ca}$ accumulation efficiencies were calculated following the same method as that used for $\mathrm{N}$ accumulation efficiency.

\section{Data analysis}

Logistic regression was used to fit the seedling height growth pattern of Cypress under different $\mathrm{Ca}^{2+}$ treatments; the fitting equation was $y=k /\left(1+a e^{-b t}\right)$, where $y$ is cumulative growth of seedling height, $t$ is the growth time, $k$ is the theoretical upper limit of height growth, and $a$ and $b$ are the undetermined coefficients. One-way analysis of variance (ANOVA) was used to assess significant differences in seedling growth, root morphological characteristics and nutrient accumulation efficiency under $\mathrm{Ca}^{2+}$ treatments in fertile and low-fertility soils. All statistical analyses were performed using IBM SPSS Statistics 22.0 (IBM Corp., Armonk, NY, USA).

\section{Results}

\section{Cypress seedling height and height growth pattern}

The seedling height of Cypress in fertile soil was significantly greater than that in low-fertility soil ( $\mathrm{P}$ $<0.01$ ). The seedling height of Cypress did not differ significantly among the $\mathrm{Ca}^{2+}$ treatments (Table 2), but did differ significantly among the clones; the $\mathrm{C} 1$ clone was significantly taller than the $\mathrm{C} 2$ clone (Fig. $1 \mathrm{~A})$.

In both soil conditions, the seedling height exhibited a "slow-fast-slow" growth pattern (Fig. 2). In the fertile soil, the fast growth period with regard to seedling height began at 61 and 69 days under the $3 \mathrm{~g} \mathrm{~kg}^{-1}$ (T2) and $6 \mathrm{~g} \mathrm{~kg}^{-1} \mathrm{Ca}^{2+}$ (T3) treatments, respectively; the beginning date was delayed by 5 and 13 days, while the duration of the fast growth period was shortened by 9 and 14 days, respectively, compared with that of the $0 \mathrm{~g} \mathrm{~kg}^{-1} \mathrm{Ca}^{2+}$ (T1) treatment. In the low-fertility soil, the fast growth period for seedling height began at 76 days after the addition of $3 \mathrm{~g} \mathrm{~kg}^{-1} \mathrm{Ca}^{2+}$ (T5); the beginning date was advanced by 5 days, while the duration of the fast growth period was prolonged by 6 days compared to that of the $0 \mathrm{~g} \mathrm{~kg}^{-1} \mathrm{Ca}^{2+}$ (T4) treatment. In contrast, the fast growth period for seedling height began at 82 days after the addition of $6 \mathrm{~g} \mathrm{~kg}^{-1} \mathrm{Ca}^{2+}$ (T6); the beginning date was delayed by 1 day, while the duration of the fast-growth period was prolonged by 4 days compared with that of the $0 \mathrm{~g} \mathrm{~kg}^{-1} \mathrm{Ca}^{2+}$ treatment (T4).

\section{Dry biomass}

$\mathrm{Ca}^{2+}$ addition had no significant effect on dry matter accumulation in the roots, stems or leaves of the Cypress $\mathrm{C} 1$ and $\mathrm{C} 2$ clones. The root, stem and leaf dry matter quality were significantly different among clones (Table 2). In the fertile soil, the mean dry biomasses of roots, stems and leaves of the $\mathrm{C} 1$ clone were 5.53, 5.97 and $10.46 \mathrm{~g}$, respectively; these mean values were $30 \%, 87 \%$ and $86 \%$ higher than those of the $\mathrm{C} 2$ clone, respectively. In the low-fertility soil, the mean dry biomasses of roots, stems and leaves of the $\mathrm{C} 1$ clone were 3.58, 2.23 and $4.50 \mathrm{~g}$, respectively; these mean values were $15.71 \%, 10.05 \%$ and $3.12 \%$ greater than those of the $\mathrm{C} 2$ clone (Fig. 1).

\section{Root growth and development}

The root length, root surface area and root volume of the D2-D4 diameter classes differed significantly among the $\mathrm{Ca}^{2+}$ treatments (Table 3 ). In the fertile soil, the addition of $\mathrm{Ca}^{2+}$ significantly inhibited the root length and root surface area of the D2 class. The sum of the root lengths of classes D1-D2 accounted for $90.9 \%, 90 \%$ and $89.1 \%$ of total root length across the three $\mathrm{Ca}^{2+}$ treatments (T1, T2 and T3, respectively); among these, the root length of the D2 class accounted for $32.0 \%, 35.2 \%$ and $36.8 \%$ of total root length, respectively. In the low-fertility soil,

Table 2. Variance analysis of seedling height, dry matter and nutrient absorption of two C. funebres clones under different NPK fertilizer and $\mathrm{CaSO}_{4}$ treatments.

\begin{tabular}{|c|c|c|c|c|c|c|c|}
\hline Traits & NPK & $\mathrm{Ca}^{2+}$ & Clones & $\mathrm{NPK} \times \mathrm{Ca}^{2+}$ & Clones $\times$ NPK & Clones $\times \mathrm{Ca}^{2+}$ & Clones $\times \mathrm{NPK} \times \mathrm{Ca}^{2+}$ \\
\hline Seedling height & $425.71^{* *}$ & 0.50 & $6.74^{* *}$ & $4.77^{* *}$ & $7.34^{* *}$ & $3.01^{* *}$ & 1.53 \\
\hline Root dry matter & $11.67^{* *}$ & 0.43 & $12.08^{* *}$ & $4.20^{*}$ & $11.19^{* *}$ & 1.34 & 1.91 \\
\hline Stem dry matter & $180.60^{* *}$ & 1.65 & $8.96^{* *}$ & 1.82 & $8.77^{* *}$ & $2.63^{* *}$ & 1.39 \\
\hline Leaf dry matter & $191.75^{* *}$ & 0.15 & $10.72^{* *}$ & 0.69 & $7.56^{* *}$ & 1.73 & 1.52 \\
\hline Nitrogen accumulation efficiencies & $268.94^{* *}$ & $4.03^{*}$ & $10.38^{* *}$ & 0.87 & $6.29 * *$ & $2.02 *$ & $2.32 *$ \\
\hline Phosphorus accumulation efficiencies & 2.08 & $4.71^{* *}$ & 1.61 & 1.69 & 1.09 & $2.73^{*}$ & 1.63 \\
\hline Calcium accumulation efficiencies & $12.34^{* *}$ & $39.14^{* *}$ & $7.26^{* *}$ & $4.62 *$ & $5.27^{* *}$ & $2.71^{*}$ & 1.76 \\
\hline
\end{tabular}

* stands for significant difference level $(\mathrm{p}<0.05),{ }^{* *}$ stands for extremely significant level $(\mathrm{p}<0.01)$. 
the addition of $3 \mathrm{~g} \mathrm{~kg}^{-1} \mathrm{Ca}^{2+}$ (T5) promoted root development of classes D2-D4, and the resulting root lengths were 1.17-, 1.15- and 1.30-fold that under the $0 \mathrm{~g} \mathrm{~kg}^{-1} \mathrm{Ca}^{2+}$ treatment (T4), respectively. The sum of the root length of classes D1-D2 accounted for $90.7 \%, 93.2 \%$ and $92.6 \%$ of the total root length across the three $\mathrm{Ca}^{2+}$ treatments (T4, T5 and $\mathrm{T} 6$, respectively). The corresponding root surface area and root volume also showed similar variation, with a 1.05-1.35-fold increase (Fig. 3).

The root length, root surface area and root volume differed significantly among Cypress clones (Table 3). In the fertile soil, the total root lengths of the $\mathrm{C} 1$ clone were $26.5 \%, 108.0 \%$ and $67.4 \%$ longer than
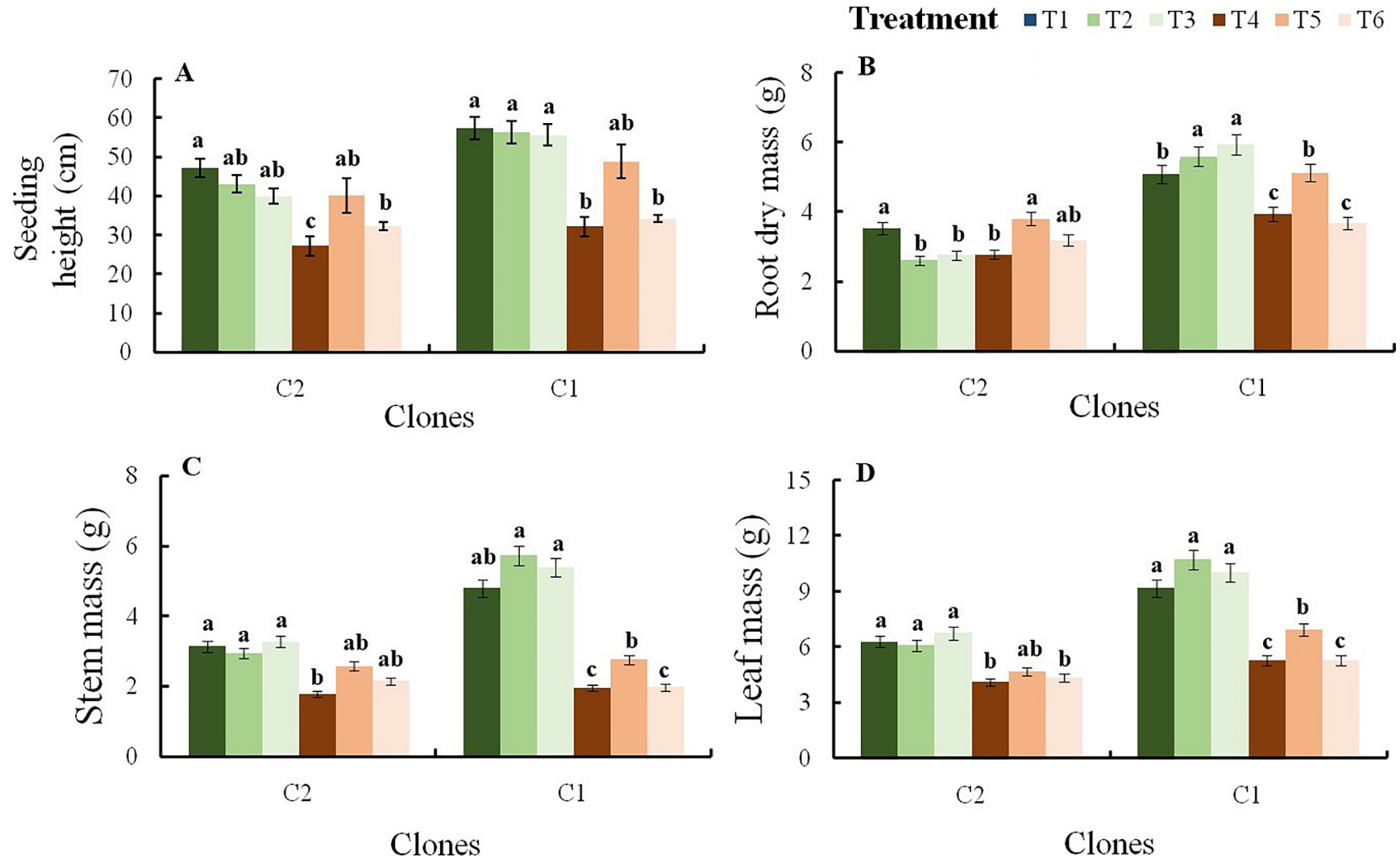

Fig. 1. Differential seeding height and dry mass of $C$. funebris clones in different solid environment and calcium treatments. Different small letters above the bars indicate the significant differences $(p<0.05)$

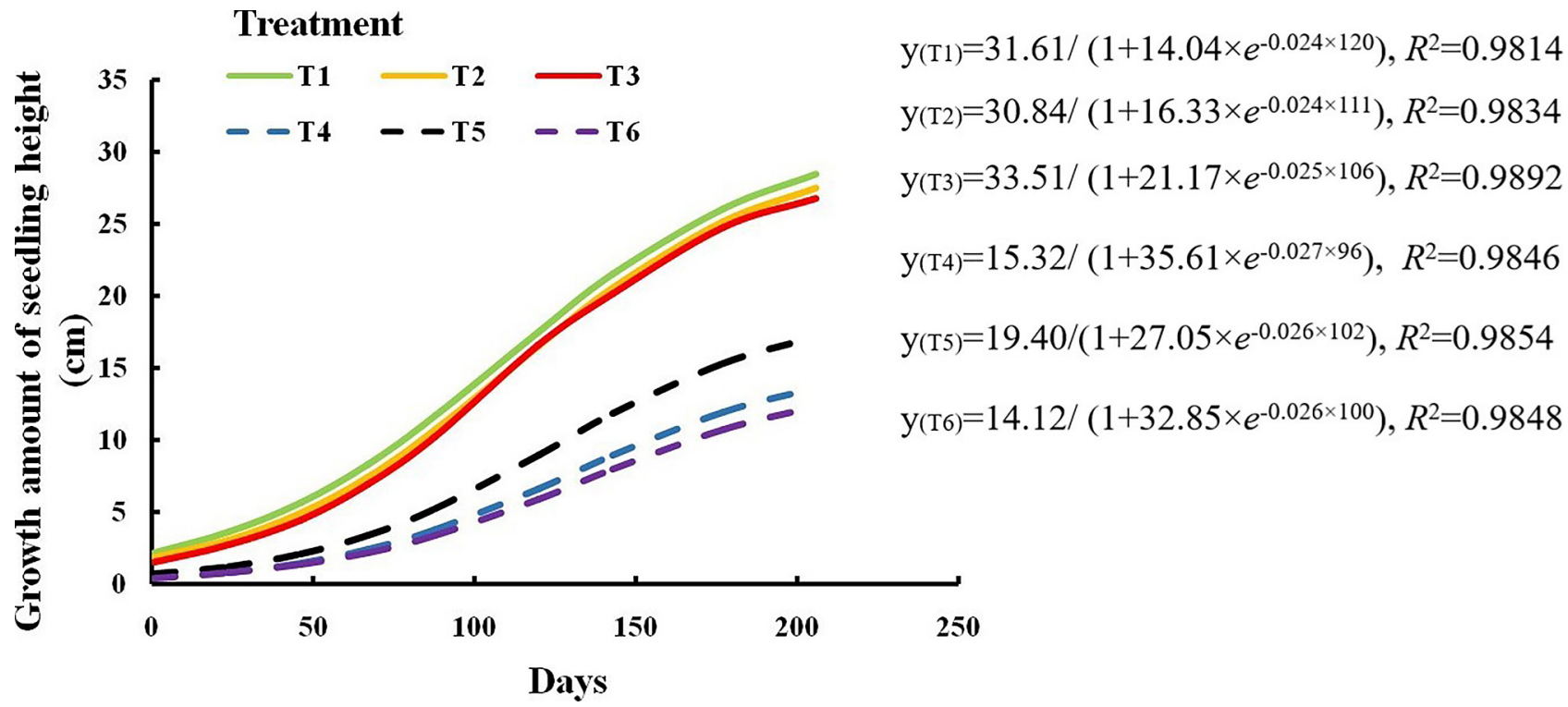

Fig. 2. Seedling height growth curve of $C$. funebris under different calcium treatments. The dotted line in the picture indicates low fertile soil and the solid line indicates fertile soil. $y$ is cumulative growth of seedling height of each treatment 
those of the $\mathrm{C} 2$ clone across the three $\mathrm{Ca}^{2+}$ treatments (T1, T2 and T3, respectively). The root surface area and root volume of the $\mathrm{Cl}$ clone were also significantly greater than those of the $\mathrm{C} 2$ clone. In the low-fertility soil, the total root lengths of in the C1 clone were $11.5 \%, 7.0 \%$ and $25.1 \%$ greater than those of the $\mathrm{C} 2$ clone across the three $\mathrm{Ca}^{2+}$ treatments (T4, T5 and T6, respectively). Similar trends were observed for root surface area and root volume (Supplementary Fig. 1).

\section{$\mathrm{N}, \mathrm{P}$ and $\mathrm{Ca}$ accumulation efficiencies}

The utilization efficiency of $\mathrm{N}$ in fertile soil was significantly greater than that in low-fertility soil, while the utilization efficiency of $\mathrm{Ca}^{2+}$ in low-fertility soil was significantly greater than that in fertile soil.
No significant difference was observed in P use efficiency between the two soil fertility conditions.

The accumulation efficiencies of $\mathrm{N}, \mathrm{P}$ and $\mathrm{Ca}$ all significantly differed among the $\mathrm{Ca}^{2+}$ treatments (Table 3). In fertile soil, $\mathrm{N}$ accumulation efficiency for both clones exhibited a downward trend with increasing $\mathrm{Ca}^{2+}$ concentration. Both clones achieved their highest $\mathrm{Ca}$ accumulation efficiency under the 6 $\mathrm{g} \mathrm{kg}^{-1} \mathrm{Ca}^{2+}$ treatment (T3) in the fertile soil. In the low-fertility soil, both the C1 and C2 clones achieved their highest $\mathrm{N}, \mathrm{P}$ and $\mathrm{Ca}$ accumulation efficiencies under the $3 \mathrm{~g} \mathrm{~kg}^{-1} \mathrm{Ca}^{2+}$ treatment (Fig. 4).

The $\mathrm{N}$ and $\mathrm{Ca}$ accumulation efficiencies significantly differed between clones, but no significant difference was detected in $\mathrm{P}$ accumulation efficiency between clones. In the fertile soil, the $\mathrm{N}$ accumulation efficiencies for C1 were $10.64 \%, 13.52 \%$ and
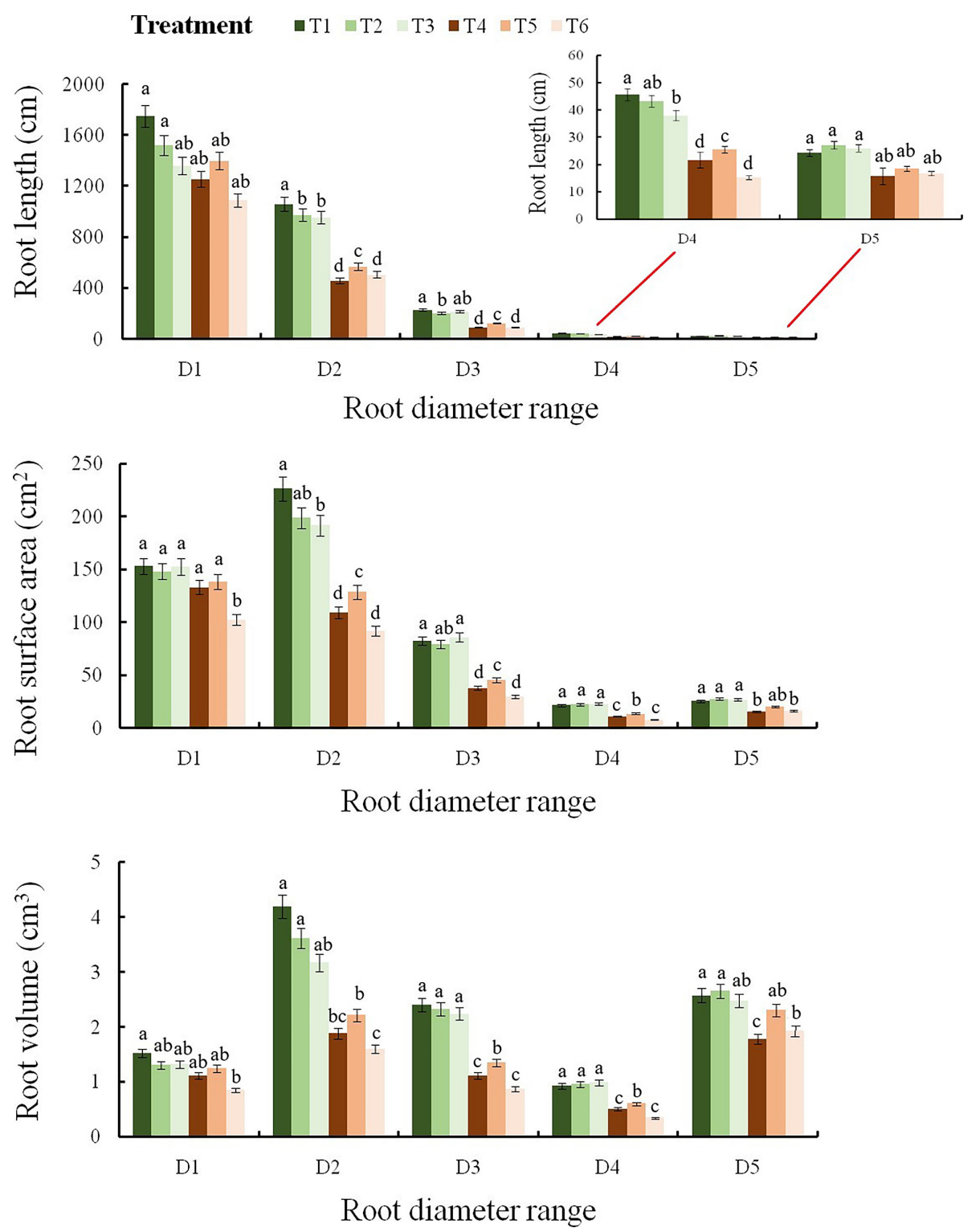

Fig. 3. Effects of calcium supply levels on root morphology of $C$. funebris clones under two soil fertility levels. Different small letters above the bars indicate the significant differences $(\mathrm{p}<0.05)$ 
3.04\% higher than those for $\mathrm{C} 2$ across the three $\mathrm{Ca}^{2+}$ treatments (T1, T2 and T3, respectively). The Ca accumulation efficiencies for $\mathrm{C} 1$ were $16.94 \%, 10.39 \%$ and $6.84 \%$ higher than those for the $\mathrm{C} 2$ clone (Supplementary Fig. 2). In the low-fertility soil, the $\mathrm{N}$ accumulation efficiencies for $\mathrm{C} 1$ were $5.16 \%, 12.69 \%$ and $11.09 \%$ higher than those for $\mathrm{C} 2$ across the three $\mathrm{Ca}^{2+}$ treatments (T4, T5 and $\mathrm{T} 6$, respectively). The $\mathrm{Ca}$ accumulation efficiencies for $\mathrm{C} 1$ were $22.93 \%$, $15.54 \%$ and $12.78 \%$ higher than those for $\mathrm{C} 2$.

\section{The interaction effect}

There was significant interaction effect between NPK fertilizer and $\mathrm{Ca}^{2+}$ for seedling height, dry matter mass and root development of the D1-D3 diameter stages of Cypress (Table 2).
A significant interaction was found between clones and $\mathrm{Ca}^{2+}$ fertilizer for seedling height, root length, root surface area and root volume of the D3-D5 diameter stages of Cypress (Table 2). In the low-fertility soil, treatment with $3 \mathrm{~g} \mathrm{~kg}^{-1} \mathrm{Ca}^{2+}$ significantly promoted seedling height growth, resulting in $34.22 \%$ and $32.19 \%$ increases in seedling height in the $\mathrm{C} 1$ and $\mathrm{C} 2$ clones, respectively, compared to the $0 \mathrm{~g} \mathrm{~kg}^{-1} \mathrm{Ca}^{2+}$ treatment. In contrast, seedling height showed a decrease following the addition of $6 \mathrm{~g} \mathrm{~kg}^{-1} \mathrm{Ca}^{2+}$ (Supplementary Fig. 3). In the fertile soil, the root length, root surface area and root volume of the D3-D5 diameter classes all significantly decreased in the $\mathrm{C} 2$ clone following $\mathrm{Ca}^{2+}$ addition. In contrast, $\mathrm{Ca}^{2+}$ addition had no significant effect on root length, root surface area or root volume in the C1 clone (Supplementary Fig. 1).

Table 3. Variance analysis of root length, surface area and volume of each diameter class of $C$. funebres clones under different NPK fertilizer and $\mathrm{CaSO}_{4}$ treatments

\begin{tabular}{ccccccccc}
\hline \multicolumn{2}{c}{ Diameter class } & NPK & $\mathrm{Ca}^{2+}$ & Clones & NPK $\times \mathrm{Ca}^{2+}$ & Clones $\times \mathrm{NPK}$ & Clones $\times \mathrm{Ca}^{2+}$ & $\mathrm{Clones}^{2} \mathrm{NPK} \times \mathrm{Ca}^{2+}$ \\
\hline Root length (cm) & $0-0.5$ (D1) & 1.84 & 0.60 & $7.03^{* *}$ & $4.62^{*}$ & $3.57^{* *}$ & 0.89 & 1.68 \\
& $0.5-1.0$ (D2) & $125.78^{* *}$ & $12.93^{* *}$ & $13.21^{* *}$ & $5.72^{* *}$ & $5.88^{* *}$ & 0.94 & $1.99^{*}$ \\
& $1.0-1.5$ (D3) & $173.76^{* *}$ & $15.01^{* *}$ & $9.22^{* *}$ & $4.79^{* *}$ & $6.34^{* *}$ & $2.05^{*}$ & $2.30^{*}$ \\
& $1.5-2.0$ (D4) & $170.69^{* *}$ & $4.58^{*}$ & $15.57^{* *}$ & 2.23 & $10.13^{* *}$ & $3.79^{* *}$ & $2.5^{*}$ \\
Root Surface area $\left(\mathrm{cm}^{2}\right)$ & $\geq 2.0$ (D5) & $48.68^{* *}$ & 0.62 & $15.02^{* *}$ & 0.13 & $8.53^{* *}$ & $3.37^{* *}$ & 0.94 \\
& $0-0.5$ (D1) & $3.49^{*}$ & 0.82 & $8.15^{* *}$ & $3.94^{*}$ & $3.88^{* *}$ & 0.88 & 1.79 \\
& $0.5-1.0$ (D2) & $132.24^{* *}$ & $13.56^{* *}$ & $12.81^{* *}$ & $6.00^{* *}$ & $5.86^{* *}$ & 0.93 & $1.98^{*}$ \\
Root volume $\left(\mathrm{cm}^{3}\right)$ & $1.0-1.5$ (D3) & $174.98^{* *}$ & $14.69^{* *}$ & $9.35^{* *}$ & $4.57^{*}$ & $6.46^{* *}$ & $2.12^{*}$ & $2.34^{*}$ \\
& $1.5-2.0$ (D4) & $169.13^{* *}$ & $4.38^{*}$ & $15.64^{* *}$ & 2.23 & $9.99^{* *}$ & $3.75^{* *}$ & $2.45^{*}$ \\
& $\geq 2.0$ (D5) & $54.97^{* *}$ & 0.98 & $13.52^{* *}$ & 0.28 & $8.01^{* *}$ & $4.02^{* *}$ & 0.87 \\
& $0-0.5$ (D1) & $6.90^{* *}$ & 1.28 & $9.03^{* *}$ & $3.18^{*}$ & $4.08^{* *}$ & 0.89 & 1.84 \\
& $0.5-1.0$ (D2) & $138.44^{* *}$ & $14.17^{* *}$ & $12.38^{* *}$ & $6.24^{* *}$ & $5.81^{* *}$ & 0.92 & $1.98^{*}$ \\
& $1.0-1.5$ (D3) & $176.23^{* *}$ & $14.33^{* *}$ & $9.51^{* *}$ & $4.35^{*}$ & $6.58^{* *}$ & $2.19^{*}$ & $2.38^{*}$ \\
& $1.5-2.0$ (D4) & $167.72^{* *}$ & $4.19^{*}$ & $15.68^{* *}$ & 2.25 & $9.82^{* *}$ & $3.70^{* *}$ & $2.40^{*}$ \\
& $\geq 2.0$ (D5) & $61.20^{* *}$ & 1.18 & $12.09^{* *}$ & 0.90 & $6.65^{* *}$ & $4.18^{* *}$ & 0.86 \\
\hline
\end{tabular}

$*_{\text {- }}$ significant difference level $(\mathrm{p}<0.05),{ }^{* *}$ - extremely significant level $(\mathrm{p}<0.01)$.

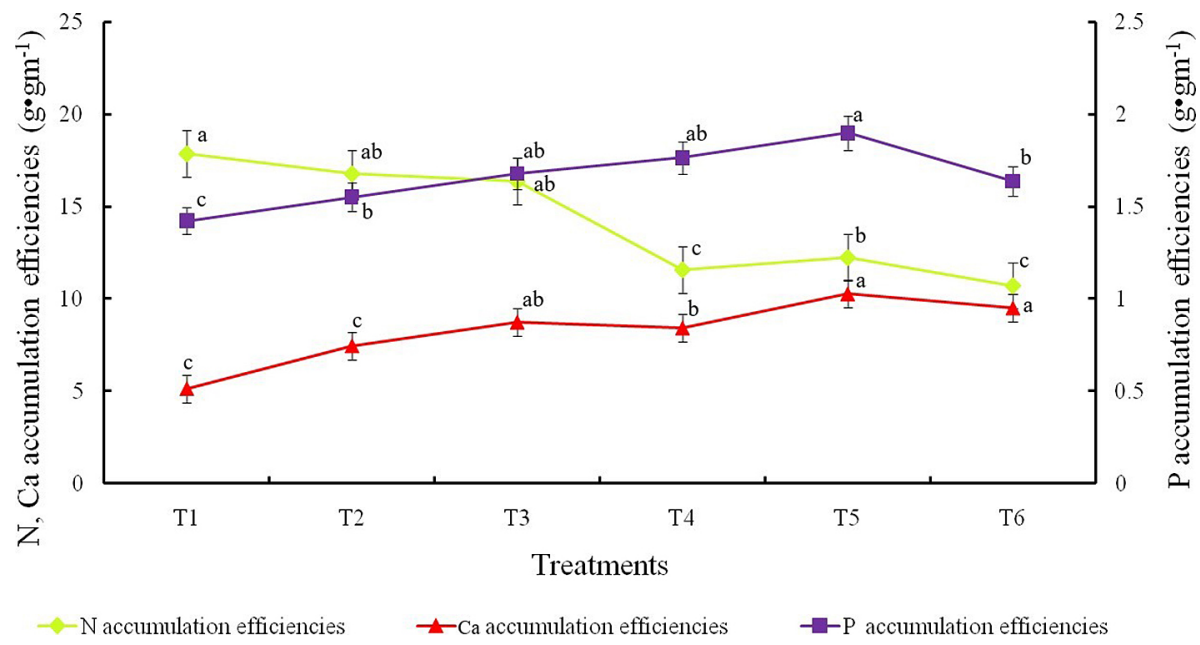

Fig. 4. Effects of calcium supply levels on absorption efficiency of nitrogen, phosphorus and calcium of C. funebris clones under two soil fertility levels. Different small letters above the line indicate the significant differences $(p<0.05)$ 


\section{Discussion}

It is generally thought that a plant is not deficient in $\mathrm{Ca}^{2+}$ when the exchangeable $\mathrm{Ca}^{2+}$ content in soil is greater than $400 \mathrm{mg} \mathrm{kg}^{-1}$. In the present study, the experimental soil contained an exchangeable $\mathrm{Ca}^{2+}$ content of $128 \mathrm{mg} \mathrm{kg}^{-1}$, which was lower than the cutoff value without $\mathrm{Ca}^{2+}$ application, thus resulting in $\mathrm{Ca}^{2+}$-deficient soil (Ji et al., 2009). Compared to that of the low-fertility soil, the seedling height of Cypress growing in fertile soil showed a reduced response to $\mathrm{Ca}^{2+}$. The addition of $\mathrm{Ca}^{2+}$ fertilizer reduced the $\mathrm{N}$ accumulation efficiency in Cypress. These observations indicate that the $\mathrm{N}$ and $\mathrm{P}$ nutrients were sufficient in the fertile soil, exchangeable $\mathrm{Ca}^{2+}$ was exchanged with a large amount of $\mathrm{NH}_{4}{ }^{+}$and $\mathrm{K}^{+}$, which facilitated the desorption of exchangeable $\mathrm{Ca}^{2+}$, and $\mathrm{N}$ accumulation efficiency decreased with increasing $\mathrm{Ca}^{2+}$ concentration (Li et al., 2017). Moreover, exchangeable $\mathrm{Ca}^{2+}$ and $\mathrm{PO}_{4}{ }^{3-}$ underwent irreversible ion exchange, and the increase in $\mathrm{P}$ promoted the conversion of water-soluble and exchangeable $\mathrm{Ca}^{2+}$ to unavailable non-acid-soluble $\mathrm{Ca}$, which also resulted in a decrease in the exchangeable $\mathrm{Ca}^{2+}$ in soil (White \& Broadley, 2003; Hirschi, 2004). This may be why $\mathrm{Ca}$ use efficiency was higher under a high $\mathrm{Ca}^{2+}$ concentration; however, the exact process still requires further investigation. In the low-fertility soil, the seedling height of Cypress was increased when an appropriate amount of $\mathrm{Ca}^{2+}\left(3 \mathrm{~g} \mathrm{~kg}^{-1}\right)$ was added, and the highest $\mathrm{N}, \mathrm{P}$ and $\mathrm{Ca}$ accumulation efficiencies were all achieved the under the $3 \mathrm{~g} \mathrm{~kg}^{-1}$ $\mathrm{Ca}^{2+}$ treatment, with a synergy between $\mathrm{Ca}^{2+}$ fertilizer versus $\mathrm{N}$ and $\mathrm{P}$ accumulation efficiencies. However, when the $\mathrm{Ca}^{2+}$ concentration was increased (6 $\mathrm{g} \mathrm{kg}^{-1} \mathrm{Ca}^{2+}$ treatment), seedling growth of Cypress clones decreased. These results indicate that the synergy had a range of adaptation to the amount of $\mathrm{Ca}^{2+}$ applied. That is, an appropriate amount of $\mathrm{Ca}^{2+}$ promoted plant $\mathrm{N}$ and $\mathrm{P}$ uptake, while an excessively high concentration of $\mathrm{Ca}^{2+}$ fertilizer resulted in an inhibitory effect (Borchert, 1986; Franceschi, 1989). In a study conducted on coniferous species such as pine (Pinus massoniana Lamb.), good adaptation was also observed in the soil environment with $\mathrm{Ca}^{2+}$ supplied at 1-2 $\mathrm{mmol} \mathrm{L}^{-1}$, while the plant height growth of pine seedlings decreased after the $\mathrm{Ca}^{2+}$ supply exceeded this concentration (Li et al., 2017). Therefore, full consideration should be given to the tolerance of tree species when applying $\mathrm{Ca}^{2+}$ to promote seedling growth.

Root architecture refers to the spatial distribution of plant roots in the soil, and it reflects the specific root characteristics of plants that form during evolution for adaptation to the environment (Eissenstat \& Yanni, 2002; Mou et al., 2013). In the low-fertility soil, the addition of $3 \mathrm{~g} \mathrm{~kg}^{-1} \mathrm{Ca}^{2+}$ promoted root development of the D2-D4 classes (diameter 0.5-2.0 $\mathrm{mm}$ ) in the $\mathrm{Cl}$ clone; when the $\mathrm{Ca}^{2+}$ concentration was increased to $6 \mathrm{~g} \mathrm{~kg}^{-1}$, root length, root surface area and root volume increases of classes D2-D4 were inhibited in this clone. Moreover, in the fertile soil, $\mathrm{Ca}^{2+}$ addition inhibited root length, root surface area and root volume increases of classes D1-D5 of the $\mathrm{C} 2$ clone. These results demonstrate that the roots of different diameter classes have distinct reactions to $\mathrm{Ca}^{2+}$ (Mou et al., 2013; Kanno et al., 2016). McCormack's method is used for functional classification of fine roots; fine roots with a diameter of 0-1.0 $\mathrm{mm}$ are absorptive roots, and fine roots with a diameter of 1.0-2.0 $\mathrm{mm}$ are transport roots (McCormack et al., 2015). The root length of absorptive roots accounted for $91.1 \%$ of the total root length, the root surface area of absorptive roots accounted for $74.8 \%$ of the total root surface, and the root volume of absorptive roots accounted for $45.2 \%$ of total root volume; the proportions of transport roots were $8.0 \%, 19.6 \%$ and $27.2 \%$, respectively. Absorptive roots are the most active components of fine roots of trees; their lignification degree is relatively low and closely related to the apical region, which is sensitive to soil nutrient changes. The root length and root surface area of absorptive fine roots enable plants to easily respond to changes in the soil environment (Eissenstat \& Yanni, 2002; Guo et al., 2008; Mou et al., 2013; Band \& Bennett, 2013). The proportion of fine roots with a diameter of $0-1.0 \mathrm{~mm}$ in low-fertility soil was higher than that in fertile soil. In the fertile soil, lateral root growth was inhibited with increasing $\mathrm{Ca}^{2+}$ concentration, which indicates that Cypress roots adapted to the $\mathrm{Ca}^{2+}$ environment by reducing lateral root growth and soil contact area under $\mathrm{Ca}^{2+}$ stress. Under low-fertility soil conditions, Cypress could adjust the morphology of fine roots to adapt to different $\mathrm{Ca}^{2+}$ environments, increasing the fine root diameter to $\leq 1.0 \mathrm{~mm}$ to improve their ability to obtain nutrients (Hodge, 2004).

\section{Conclusions and implications for forest practice}

In conclusion, adding calcium fertilizer under two soil conditions affected the growth of fine roots of Cypress clonal seedlings and the element accumulation of $\mathrm{N}, \mathrm{P}$ and $\mathrm{Ca}$, thus influencing seedling growth. Under fertile soil conditions, addition of $\mathrm{Ca}$ fertilizer inhibited effective $\mathrm{N}$ accumulation of $\mathrm{Cy}$ press and significantly inhibited the development of root length in roots $0.5-1.0 \mathrm{~mm}$ in diameter. Therefore, for Cypress clones grown under fertile soil conditions, addition of $\mathrm{Ca}^{2+}$ fertilizer should not be considered. Under low-fertility soil conditions, the addition of $\mathrm{CaSO}_{4}$ can promote the root development 
of seedlings to some extent and advance and prolong the fast growth period of seedling height. Therefore, Cypress clones can be used as a major tree species for afforestation under low-fertility soil conditions and especially under calcareous soil conditions.

\section{Acknowledgments}

This work was supported by Zhejiang Science and Technology Major Program on Agricultural New Variety Breeding of China (2016C02056-5). We acknowledge the help form Zhongcheng $\mathrm{Lu}$ and Tan Chen with sample collection at the study site. We thank Yi Zheng and Chengzhi Yuan for input on the manuscript.

\section{References}

Abbasi MK \& Manzoor M (2013) Effect of soil-applied calcium carbide and plant derivatives on nitrification inhibition and plant growth promotion. International Journal of Environmental Science and Technology 10: 961-972.

Anderson JM \& Ingram JSI (1993) Tropical soil biology and fertility: a handbook of methods. 2th ed. Wallingford, Oxfordshire: $\mathrm{CAB}$ International.

Azevedo LB, Zelm RV, Hendriks AJ, Bobbink R \& Mark AJH (2013) Global assessment of the effects of terrestrial acidification on plant species richness. Environmental Pollution 174: 10-15.

Band LR \& Bennett MJ (2013) Mapping the site of action of the green revolution hormone gibberellin. Proceedings of the National Academy of Science of the United States of America 110: 4443-4444. doi:10.1073/pnas.1301609110.

Borchert R (1986) Calcium acetate induces calcium uptake and formation of calcium-oxalate crystals in isolated leaflets of Gleditsia triacanthos L. Planta 168: 571-578.

Brunner I, Herzog C, Galiano L \& Gessler A (2019) Plasticity of Fine-Root Traits Under Long-Term Irrigation of a Water-Limited Scots Pine Forest. Frontiers in Plant Science 10: e701.

Chan CWM, Wohlbach DJ, Rodesch MJ \& Sussman MR (2008) Transcriptional changes in response to growth of Arabidopsis in high external calcium. FEBS Letters 582: 967-976. doi:10.1016/j.febslet.2008.02.043.

Chen W, Koide RT, Adams TS, DeForest JL, Cheng L \& Eissenstat DM (2016) Root morphology and mycorrhizal symbioses together shape nutrient foraging strategies of temperate trees. Proceedings of the National Academy of Sciences USA 113: 8741-8746.

Rogers ED \& Benfey PN (2015) Regulation of plant root system architecture: implications for crop advancement. Current Opinion in Biotechnology 32: 93-98.

Eissenstat DM, Kucharski JM, Zadworny M, Adams TS \& Koide RT (2015) Linking root traits to nutrient foraging in arbuscular mycorrhizal trees in a temperate forest. New Phytologist 208: 114-124.

Eissenstat DM \& Yanni RD (2002) Root lifespan, efficiency and turnover: Plant roots: The hidden half. 3rd ed. (ed. by Y Waisel, A Eshel \& U Kafkafi U) Dekker, New York, CRC Press, pp. 221-238.

Franceschi VR (1989) Calcium oxalate formation is a rapid and reversible process in Lemna minor $\mathrm{L}$. Protoplasma 148: 130-137.

Paez-Garcia A, Motes CM, Scheible WR, Chen RJ, Blancaflor EB \& Monteros MJ (2015) Root traits and phenotyping strategies for plant improvement. Plants 4: 334-355.

Guo DL, Li H, Mitchell RJ, Han WX, Hendricks JJ, Fahey TJ \& Hendrick RL (2008) Heterogeneity by root branch order: Exploring the discrepancy in root longevity and turnover estimates between minirhizotron and $\mathrm{C}$ isotope methods. New Phytologist 177: 443-456. doi:10.1111/ j.14698137.2007.02242.x.

Goulding KWT (2016) Soil acidification and the importance of liming agricultural soils with particular reference to the United Kingdom. Soil Use and Management 32: 390-399. doi.org:10.1111/ sum. 12270 .

He YL, Liu A, Tigabu M, Wu P, Ma X, Wang C \& Oden PC (2013) Physiological responses of needles of Pinus massoniana elite families to phosphorus stress in acid soil. Journal of Forest Research 24: 325-332.

Hepler PK (2005) Calcium: a central regulator of plant growth and development. Plant Cell 17: 2142-2155. doi:10.1105/tpc.105.032508.

Hirschi KD (2004) The calcium conundrum, both versatile nutrient and specific signal. Plant Physiology 136: 2438-2442. doi:10.1104/pp.104.046490.

Hodge A (2004) The plastic plant: Root responses to heterogeneous supplies of nutrients. New Phytologist 162: 9-24. doi:10.1111/j.14698137.2004.01015.x.

Jammes F, Hu HC, Villiers F, Bouten R \& Kwak JM (2011) Calcium permeable channels in plant cells. FEBS J 278: 4262-4276. doi:10.1111/j.1742-4658. 2011.08369.x.

Ji FT, Li N \& Deng X (2009) Calcium contents and high calcium adaptation of plants in karst areas of China. Chinese Journal of Plant Ecology 33: 926-935.

Kanno S, Arrighi JF, Chiarenza S, Bayle V, Bethome R, Peret B, Javot H, Del-annoy E, Marin E, Nakanishi TM, Thibaud MC \& Nussaume L (2016) A novel role for the root cap in phosphate uptake 
and homeostasis. eLife 5: e14577. doi:10.7554/ eLife. 14577.

Katerji N \& Mastrorilli M (2009) The effect of soil texture on the water use efficiency of irrigated crops: results of a multi-year experiment carried out in the Mediterranean region. European Journal of Agronomy 30: 95-100.

Kinzel H (1989) Calcium in the vacuoles and cell walls of plant tissue. Flora 182: 99-125. doi:10.1016/ S0367-2530(17)30398-5.

Kong XP, Zhang ML, Smet ID \& Ding ZJ (2014) Designer crops: optimal root system architecture for nutrient acquisition. Trends in Biotechnology 32: 597-598. doi:10.1016/j.tibtech.2014.09.008.

Kudla J, Batistič O \& Hashimoto K (2010) Calcium signals: the lead currency of plant information processing. Plant Cell 22: 541-563.

Li DY\&Zhou YC (2017) Effects of calcium concentration on growth and physiological characteristics of Pinus massoniana seeding. Forest Research 30: 174-180.

Li P, Li CY, Wang YQ \& Jiao CQ (2017) Effects of fertilizing regime and planting age on soil calcium decline in Luochuan apple orchards. Chinese Journal of Applied Ecology 28: 1611-1618.

Liu B, Li HB, Zhu B, Koide RT, Eissenstat DM \& Guo DL (2015) Complementarity in nutrient foraging strategies of absorptive fine roots and arbuscular mycorrhizal fungi across 14 coexisting subtropical tree species. New Phytologist 208: 125-136.

Liu Y, Wang G, Yu KX, Li P, Xiao L \& Liu GB (2018) A new method to optimize root order classification based on the diameter interval of fine root. Scientific Reports 8: e2960.

McCormack ML, Dickie IA, Eissenstat DM, Fahey TJ, Fernandez CW, Guo DL, Helmisaari HS, Hobbie EA, Iversen CM, Jackson RB, Leppälammi-Kujansuu J, Norby RJ, Phillips RP, Pregitzer KS, Pritchard SG, Rewald B \& Zadworny M (2015) Redefining fine roots improves understanding of below-ground contributions to terrestrial biosphere processes. New Phytologist 207: 505-518.

McCormack ML, Guo D, Iversen CM, Chen WL4, Eissenstat DM, Fernandez CW, Li L, Ma CG, Ma ZQ, Poorter H, Reich PB, Zadworny M \& Zanne A (2017) Building a better foundation: improving root-trait measurements to understand and model plant and ecosystem processes. New Phytologist 215: 27-37.

Meinen C, Hertel D \& Leuschner C (2009) Biomass and morphology of fine roots in temperate broadleaved forests differing in tree species diversity: is there evidence of below-ground overyielding? Oecologia 161: 99-111.

Mommer L, van Ruijven J, Jansen C, van de Steeg HM \& de Kroon H (2012) Interactive effects of nutrient heterogeneity and competition: Implications for root foraging theory? Functional Ecology 26: 66-73. doi:10.1111/j.1365-2435.2011.01916.x.

Mou P, Robert HJ, Tan ZQ, Bao Z \& Chen HM (2013) Morphological and physiological plasticity of plant roots when nutrients are both spatially and temporally heterogeneous. Plant and Soil 364: 373-384. doi:10.1007/s11104-012-1 336-y.

Rashid MHU, Tigabu M, Chen H, Farooq TH, Ma XQ \& Wu PF (2020) Calcium-mediated adaptive responses to low phosphorus stress in Chinese fir. Trees 43: 825-834. doi:10.1007/s00468-02001961-4.

Strand AE, Pritchard SG, McCormack ML, Davis MA \& Oren R (2008) Irreconcilable differences: Fineroot life spans and soil carbon persistence. Science 319: 456-458.

Tracy SR, Nagel KA, Postma JA, Fassbender H, Wasson A \& Watt M (2019) Crop improvement from phenotyping roots: Highlights reveal expanding opportunities. Trends in Plant Science 25: 105118. doi:10.1016/j.tplants.20 19.10.015.

White PJ \& Broadley MR (2003) Calcium in plants. Annals of Botany 92: 487-511. doi:10.1093/aob/ mcg164. 